\title{
Effect of Irrigation with Sea Water on Germination and Growth of Lentil (Lens culinaris Medic)
}

\author{
Basel Natsheh $^{1}$, Zaher Barghouthi ${ }^{2}$, Sameer Amereih ${ }^{1}$, Mazen Salman ${ }^{1 *}$ \\ ${ }^{1}$ Palestine Technical University-Kadoorei, Tullkarm, Palestine \\ ${ }^{2}$ Department of Natural Resources Research, National Agricultural Research Center (NARC), Jenin, Palestine \\ Email: *salman_mazen@daad-alumni.de
}

Received February 26, 2012; revised March 19, 2012; accepted April 23, 2012

\begin{abstract}
In an attempt to evaluate the efficiency of sea water irrigation on plant growth and germination, five cultivars of lentil ILL4400, 5582, 5845, 5883 and 8006 were grown in sandy soil and irrigated with sea water of different salinity levels (Ec 0.9-12). Percent of germination, seedlings lengths and mean germination time were recorded. The results showed that all cultivars were able to germinate at different salinity levels. The germination percent was increased. The percent of seed germination was significantly higher in cultivars ILL8006 and ILL5883. Sea water of salinities Ec3 and Ec6 was ideal for irrigation without negative impacts on lentil germination and growth. At higher salinity (Ec12) the germination rate was reduced and the mean germination time was greater than that in lentil seeds irrigated with sea water of Ec 0.9-9.
\end{abstract}

Keywords: Lentil; Germination; Seedling; Salinity; Sea Water

\section{Introduction}

The limited water resources in many parts of the world form a major constraint for agricultural and socio-economic development [1]. In arid and semi-arid areas, salinity is one of the most pronounced problems of agricultural irrigation. In these regions, there is an urgent need to use saline water in irrigation because of limited water resources. The success of using saline water for economic crop production can be achieved using best management practices to reduce the negative effects of salinity on crop productivity. In addition to that, introduction and cultivation of crops and varieties that tolerate salinity is highly required.

With increasing demand for irrigation water, alternative sources are being sought. Saline water was previously considered unusable for irrigation. However, this water can be used successfully to grow crops under certain conditions [2]. Saline water has been used in different crops including food, fuel and fodder crops [3]. However, seed germination is the major factor limiting the establishment of plants under saline conditions. Salinity may cause significant reductions in the rate and percentage of germination, which in turn may lead to uneven stand establishment and reduced crop yields [4]. Salt stress reduces the total dry matter, and relative water content, but increases proline accumulation, enzyme activities and electrolyte leakage [5,6]. The aim of this

\footnotetext{
*Corresponding author.
}

work was to characterize the effect of salinity on lentil germination. Addressing these issues may help generate knowledge valuable for production programs of lentil under saline conditions.

\section{Materials and Methods}

\subsection{Plant and Growth Conditions}

Lentil (Lens culinaris) cultivars ILL4400, 5582, 5845, 5883 and 8006 were used as the test plant species. Seeds were obtained from ICARDA, Aleppo, Syria. The greenhouse experiments were conducted at the Mediterranean Agronomic Institute, Valenzano, Bari, Italy South coast. All experiments were performed in greenhouse cabins at $20^{\circ} \mathrm{C}$ and $14 \mathrm{~h}$ light and at $18^{\circ} \mathrm{C}$ in the dark for $10 \mathrm{~h} /$ day. The plants were grown in pure sand in plastic pots $(15 \times$ $15 \times 7 \mathrm{~cm})$.

\subsection{Irrigation Water}

Saline water was prepared by mixing fresh water (0.9 $\mathrm{ds} / \mathrm{m}$ ) with sea water $(48 \mathrm{ds} / \mathrm{m}$ ) to achieve salinity levels of 3.0, 6.0, 9.0 and $12.0 \mathrm{ds} / \mathrm{m}$. The chemical and physical compositions of irrigation water were determined at the laboratory (Table 1). The electrical conductivity (EC), soluble cations $\left(\mathrm{Ca}^{2+}, \mathrm{Mg}^{2+}, \mathrm{Na}^{+}\right.$and $\left.\mathrm{K}^{+}\right)$, and soluble anions $\left(\mathrm{CO}_{3}^{-}, \mathrm{HCO}_{3}^{-}, \mathrm{Cl}^{-}\right.$and $\left.\mathrm{SO}_{4}^{-}\right)$were tested. EC was determined using conductivity meter (Crison micro CM 2201) and expressed in $\mathrm{ds} / \mathrm{m}$. The $\mathrm{pH}$ was measured 
Table 1. Chemical characteristics of water used in irrigation.

\begin{tabular}{|c|c|c|c|c|c|c|c|c|c|}
\hline \multirow{2}{*}{$\begin{array}{c}\text { EC } \\
(\mathrm{ds} / \mathrm{m})\end{array}$} & \multirow{2}{*}{$\mathrm{pH}$} & \multicolumn{3}{|c|}{$\begin{array}{l}\text { soluble anions } \\
\text { (meq/l) }\end{array}$} & \multicolumn{4}{|c|}{$\begin{array}{c}\text { soluble cations } \\
\text { (meq/l) }\end{array}$} & \multirow{2}{*}{$\begin{array}{l}\text { SAR } \\
(\mathrm{meq})^{1 / 2}\end{array}$} \\
\hline & & $\mathrm{HCO}_{3}$ & $\mathrm{Cl}$ & $\mathrm{SO}_{4}^{-}$ & $\mathrm{Ca}$ & $\mathrm{Mg}$ & $\mathrm{Na}$ & K & \\
\hline $0.9^{*}$ & 7.4 & 4.3 & 3.15 & 0.8 & 5.4 & 2.75 & 2.0 & 0.25 & 0.99 \\
\hline 3.0 & 7.6 & 4.6 & 24.8 & 0.7 & 6.3 & 10.2 & 18.7 & 1.2 & 6.57 \\
\hline 6.0 & 7.7 & 5.2 & 53.2 & 1.6 & 6.8 & 16.7 & 40.0 & 2.5 & 11.67 \\
\hline 9.0 & 7.9 & 5.5 & 83.4 & 1.95 & 8.6 & 23.7 & 60.1 & 3.6 & 14.93 \\
\hline 12.0 & 8.0 & 5.9 & 118 & 2.31 & 9.7 & 29.4 & 83.5 & 4.49 & 18.88 \\
\hline
\end{tabular}

using pH meter (CRISON Basic 20). $\mathrm{Ca}^{2+}$ and $\mathrm{Mg}^{2+}$ were determined by titration with EDTA $(0.01 \mathrm{~N})$ according to versenate method [7], using ammonium purporate as an indicator for $\mathrm{Ca}$ and ECBT as indicator for $\mathrm{Ca}$ and $\mathrm{Mg}$ [7]. $\mathrm{Na}$ and $\mathrm{K}$ were measured photometricaly using a flame photometer (JENWAY PEP 7) as mentioned in Richards [7]. $\mathrm{CO}_{3}$ and $\mathrm{HCO}_{3}$ were estimated volumetriccally by titration with a standard solution of sulphuric $(0.01 \mathrm{~N})$, using phenolphthalein and methyl-orange as indicators for $\mathrm{CO}_{3}$ and $\mathrm{HCO}_{3}$, respectively. $\mathrm{Cl}$ was determined by titration with a standard solution of silver nitrate $\left(\mathrm{AgNO}_{3}\right)$ in presence of $\mathrm{K}_{2} \mathrm{Cr}_{2} \mathrm{O}_{7}(1 \%)$ an indicator. Sulfate was calculated by the difference between, cations and anions.

\subsection{Experimental Design}

The experiment was conducted in randomized block design. After sowing, seeds were irrigated with sea water for three weeks. After that, number of seedlings was counted and the percent of germination was calculated.In order to determine the mean germination time, seedlings stand was recorded every two days after sowing. Mean germination time (MGT) was calculated according to the equation of Ellis and Roberts [8].

The effect of salinity on lentil growth was also studied by measuring seedling length at the end of the experiment.

\subsection{Statistical Analysis}

For statistical analysis, XIStat program (Adinosoft) was used. Data on the percent of germination were Asin-transformed. All data were analyzed for variance by Analysis of Variance (ANOVA). Significant differences among treatments were computed after Tukey HSD test at $P<$ 0.05 .

\section{Results and Discussion}

\subsection{Percent Germination}

The effect of salinity on germination is presented at Figure 1. Rate of germination and final germination per-

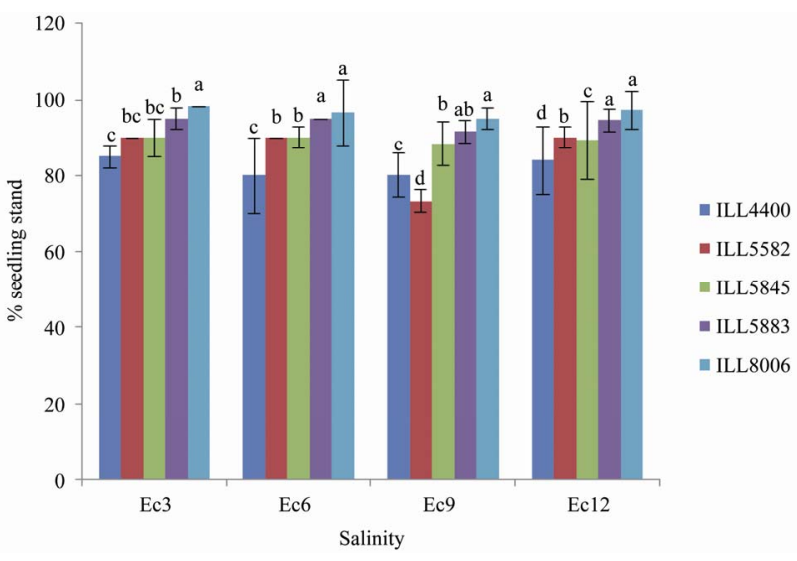

Figure 1. Germination percentage of lentil cultivars under irrigation with sea water of different salinity concentrations. Data of different letters are significantly different after ANOVA at $\mathbf{P}<\mathbf{0 . 0 5}$. Bars represent standard errors.

centage differed significantly between cultivars after irrigation with sea water of different salinity levels. Our results showed that germination of lentil seeds was not affected due to increasing salinity concentrations. Seed germination was recorded 7 days after sowing (DAS) and continued every two day over a period of 11 days (Figure 1). The highest percent of germination (100\%) was recorded in cultivar ILL 5883 irrigated with sea water of Ec 3 salinity. In cultivars ILL 5883 and ILL 8006 the percent of seed germination (100\% and $99.15 \%$, respectively) was significantly $(\mathrm{P}<0.05)$ higher in seeds irrigated with fresh water and saline water of Ec 3. The lowest percent of germination was recorded in cultivar 5582 (89.5\% and 90\%) in seeds irrigated with water of Ec 0 and Ec 3, respectively.

Compared to the control treatments (i.e. fresh water irrigation), germination was enhanced after sea water application. Salinity is a major environmental stress factor that affects seed germination [9]. In contrast to what was achieved by Abazrian et al. [3], who reported a significant decrease in seed germination of different lentil cultivars with increasing salinity levels, our results showed an enhanced germination percentage after application of sea water.

Our results also showed that the different lentil cultivars were able to grow at different salinity concentration. The ranking of cultivars regarding the germination percent is presented in Table 2.

\subsection{Seedlings Lengths}

Germination and seedling stages are very sensitive to salinity. The failure development healthy seedlings will definitely lead to failure in yield production under saline irrigation practices. Seedlings should be well developed to sustain the harmful effects opposed due to continuous irrigation with saline water. 
Table 2. Ranking for different lentil cultivars for the tolerance of salinity.

\begin{tabular}{ccccccc}
\hline & \multicolumn{5}{c}{ Ec of Sea Water } \\
\hline Varieties & $\mathbf{0 . 9}$ & $\mathbf{3}$ & $\mathbf{6}$ & $\mathbf{9}$ & $\mathbf{1 2}$ & Average \\
\hline ILL4400 & 4 & 4 & 5 & 5 & 5 & 5 \\
ILL5582 & 2 & 3 & 2 & 3 & 3 & 3 \\
ILL5845 & 5 & 5 & 4 & 4 & 4 & 4 \\
ILL5883 & 3 & 1 & 1 & 1 & 2 & 1 \\
ILL8006 & 1 & 2 & 3 & 2 & 1 & 2 \\
\hline
\end{tabular}

For the calculation of the mean ranking, scores were added and divided by 5 .

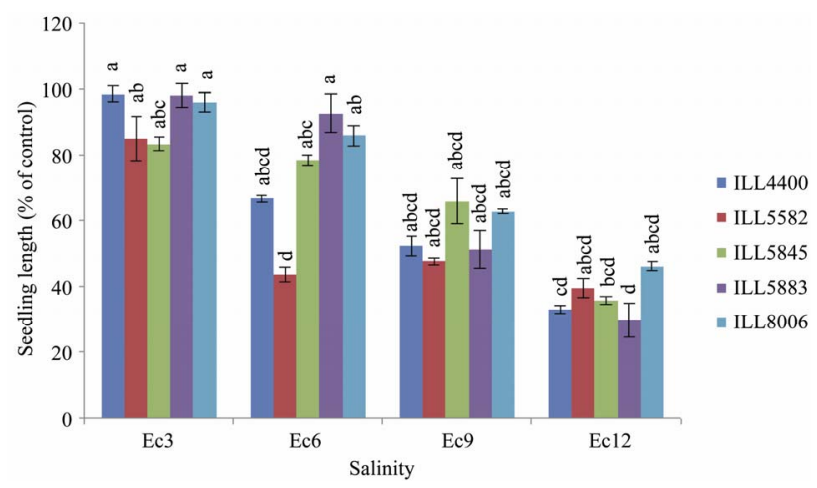

Figure 2. Seedlings lengths in $(\mathrm{cm})$ for the investigated lentil cultivars under saline irrigation treatments. Figures represent the percent of seedlings lengths compared to the control. Data of different letters are significantly different after ANOVA at $\mathbf{P}<\mathbf{0 . 0 5}$. Bars represent standard errors.

The interaction of cultivar $\times$ salinity stem length was significant different after ANOVA using Tukeys HSD test at $\mathrm{P}<0.05$. The seedlings lengths of the investigated cultivars are presented in (Figure 2). Results showed that salinity decreased plant height. Under fresh water irrigation, all cultivars showed higher stem lengths. However, no significant differences were found in stem lengths between cultivars irrigated with fresh water and cultivars irrigated with saline water of Ec 3. The highest stemlength $(18.2 \mathrm{~cm})$ was recorded in cultivar ILL 5883 irrigated with fresh water followed by cultivar ILL 4400 $(17.7 \mathrm{~cm})$.

\subsection{Mean Germination Time}

Germination is a critical phase in plant growth that determines plant establishment and final crop yield [2]. The presented data demonstrate that the gradual increments in Ec values of irrigation water did not stop the germination process of lentil seeds. However, seed germination was delayed in some cultivars after irrigation with sea water of higher EC values (Figure 3). Higher reduction of germination was recorded in seeds irrigated with sea water of Ec 12. Our results revealed that the rate of germination varied between different cultivars. In most culti-

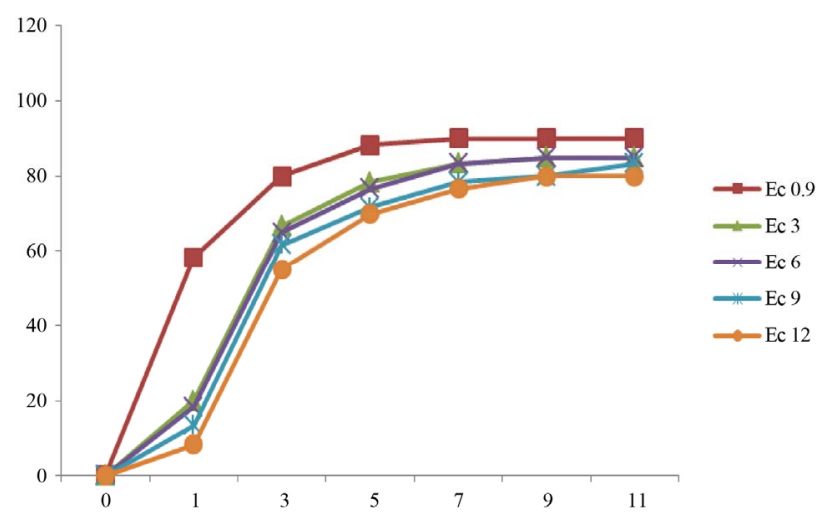

(a)

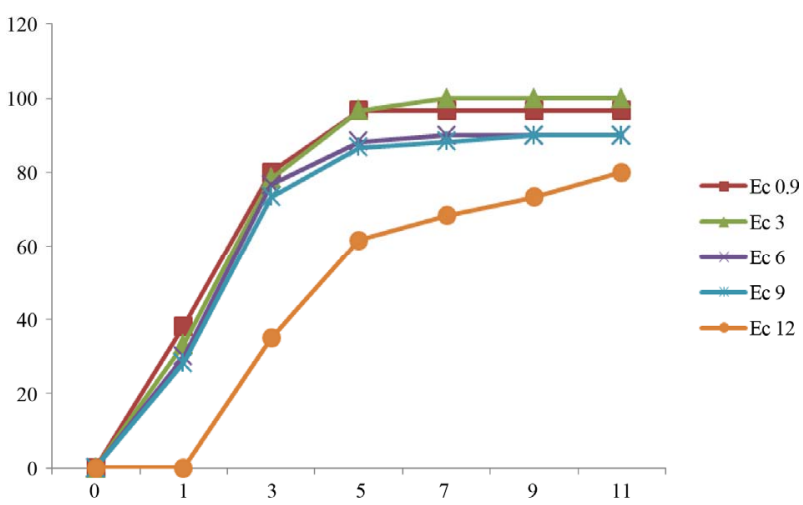

(b)

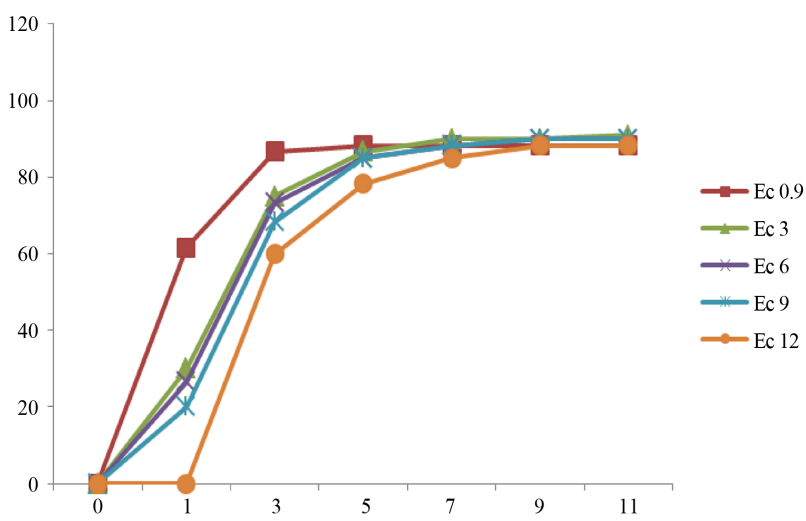

(c)

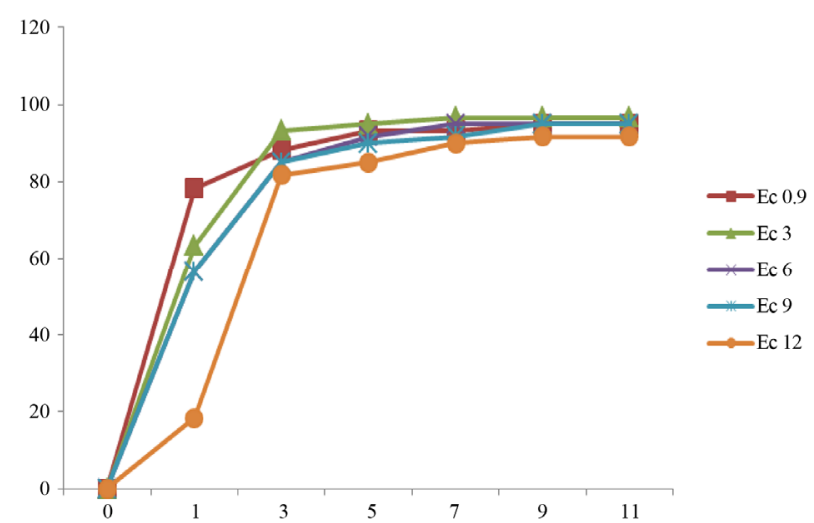

(d) 


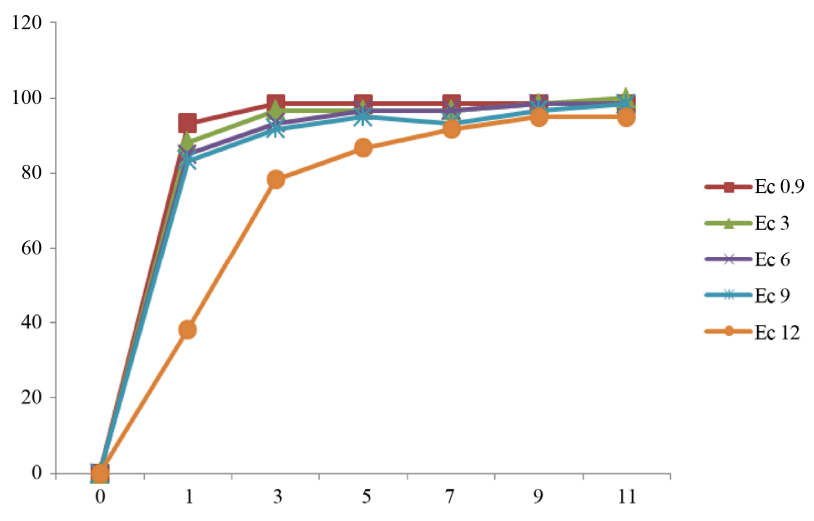

(e)

Figure 3. Mean gemrination times of lentile cultivars irrigated with sea water of different salinity levels. (a) ILL4400, (b) ILL5582, (c) ILL5845, (d) ILL5883 and (e) ILL8006.

vars complete germination was lower than $80 \%$ after 11 day after sowing. Seeds of cultivars ILL8006 and ILL5883 were the first to germinate followed by cultivars ILL5845, ILL5582 and ILL4400.

\section{Conclusion}

The use of sea water as in agriculture offers an alternative substitute to fresh water in areas suffering from water scarcity. In fact our work showed that irrigation with saline water did not affect germination of lentil seed. However, further experiments are needed to evaluate the effect of saline water irrigation on yield and crop production.

\section{Acknowledgements}

The authors would like to thank the Palestine Technical University-Kadoorie for providing financial support to publish this work.

\section{REFERENCES}

[1] A. Hamdy, "Saline Irrigation Management for a Sustainable Use,” In: N. Katerji, A. Hamdy, I. W. Van Hoorn and M. Mastrorilli, Eds., Mediterranean Crop Responses to Water and Soil Salinity: Eco-Physiological and Agronomic Analyses CIHEAM-IAMB, Bari, 2002, pp. 185-229.

[2] I. M. Zeid, "Alleviation of Seawater Stress during Germination and Early Growth of Barley," International Journal of Agriculture: Research and Review, Vol. 1, No. 2, 2011, pp. 59-67.

[3] R. Abazarian, M. R. Yazdani, K. Khosroyar and P. Arvin, "Effects of Different Levels of Salinity on Germination of four Components of Lentil Cultivars," African Journal of Agricultural Research, Vol. 6, No. 12, 2011, pp. 27612766.

[4] M. R. Foolad and G. Y. Lin, "Genetic Potential for Salt Tolerance during Germination in Lycopersicon Species," Horticulture Science, Vol. 32, 1997, pp. 296-300.

[5] A. L. Tuna, C. Kaya, M. Dikilitas and D. Higgs, "The Combined Effects of Gibberellic Acid and Salinityon Some Antioxidant Enzyme Activities, Plant Growth Parameters and Nutritional Status in Maize Plants," Environmental Experiments in Botany, Vol. 62, No. 1, 2008, pp. 1-9. doi:10.1016/j.envexpbot.2007.06.007

[6] A. Nitika, B. Renu, S. Priyanka and H. K. Arora, “28Homobrassinolide Alleviates Oxidative Stress in SaltTreated Maize (Zea mays L.) Plants,” Brazian Journal of Plant Physioliolgy, Vol. 20, 2008, pp. 153-157.

[7] L. A. Richards, “Agriculture Handbook No. 60,” US Government Printing Office, Washington DC, 1954.

[8] R. A. Ellis and E. H. Roberts, "The Quantification of Ageing and Survival in Orthodox Seeds," Seed Science and Technology, Vol. 9, 1981, pp. 373-409.

[9] A. Khan and B. Gul, "Halophyte Seed Germination: Success and Pitfalls,” In: M. A. Khan and D. J. Weber, Eds., Ecophysiology of High Salinity Tolerant Plants, Springer, Dordrecht, 2006, pp. 11-31. doi:10.1007/1-4020-4018-0_2 